\title{
Caspian Sea Convention: the settlement of the long- lasting dispute and its implications
}

\author{
Temirtay Toktassynov \\ East China Normal University, China
}

Doi: 10.19044/elp.v6no3a1

URL:http://dx.doi.org/10.19044/elp.v6no3a1

\begin{abstract}
In 2018 five Caspian states - Iran, Russia, Azerbaijan, Kazakhstan, and Turkmenistan reached a consensus on the legal status of the Caspian Sea. The governments of the respective countries have settled the long-lasting disagreement by specifying the Caspian Sea as a sea with a "special legal status." This paper argues that despite the existing disputes in the southern part of the Caspian Sea, which were not addressed in the new agreement, the adoption of the convention is a huge achievement for all littoral states. Russia and Iran have achieved their security interests by banning the military presence of non-Caspian states, while Azerbaijan and Turkmenistan have received a green light to construct a Trans-Caspian pipeline to EU from Turkmenistan, allowing Turkmen gas to circumvent Russia. Kazakhstan with the largest coastline and the biggest offshore oilfields located in the North of the Caspian has secured its sea borders stipulated by the earlier bilateral and trilateral agreements with Russia and Azerbaijan and can expand its oil exports that are presently constrained to China and Russia.
\end{abstract}

Keywords: Caspian Sea, Convention, Russia, Central Asia, security.

\section{Introduction}

The Caspian region is a vital oil-producing area in the world and is an increasingly significant source of international energy production. The region embodies forty-eight billion barrels of oil while its natural gas reserves exceed two-hundred-ninety-two trillion cubic feet (tcf), both from onshore and offshore fields. ${ }^{1}$ The nations in the Caspian region - Kazakhstan, Turkmenistan, Azerbaijan, in particular, are believed to be sitting on $10 \%$ of the global potential oil reserves ${ }^{2}$.

$1 \mathrm{https}: / /$ www.eia.gov/beta/international/regions-topics.php?RegionTopicID=CSR

$2 \mathrm{https} / / / \mathrm{www}$. infoplease.com/science-health/energy/oil-caspian-region 


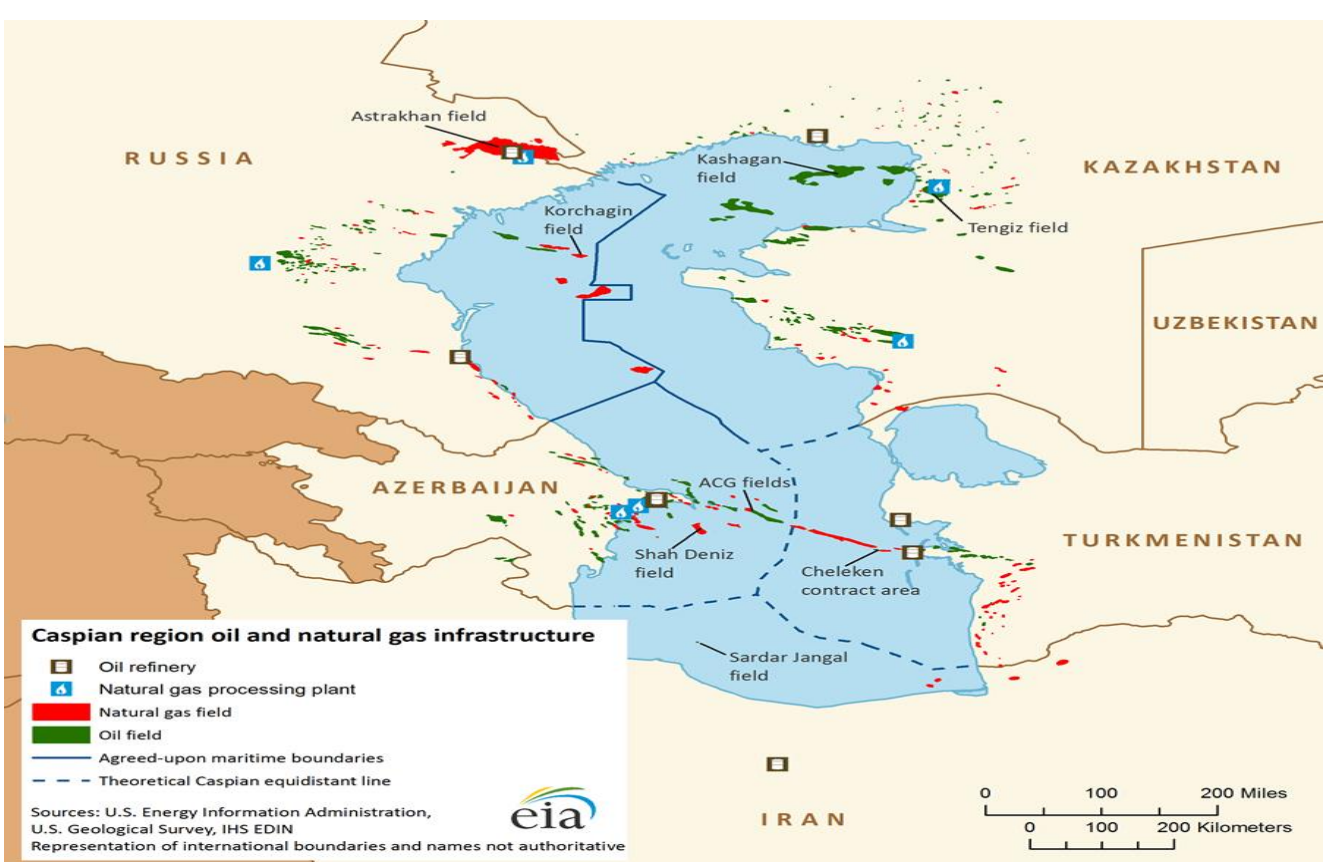

Figure 1 Caspian Sea oil and gas infrastructure

Source: US energy information agency

The Caspian seabed's oil and gas reserves are comparable to entire oil and gas reserves of the United States. ${ }^{3}$ Russia possesses the world's number one largest natural gas reserves, ensued by Iran at number two, Turkmenistan ranked at sixth place, Kazakhstan making fifteen while Azerbaijan ranks at twenty-six place. ${ }^{4}$ Generally, the majority of the oil reserves are in the North Caspian region, while the South Caspian part contains the bulk of the natural gas reserves ${ }^{5}$. Also, Caspian region considered to be primary geopolitical interest by global powers, as they are not dominated by the Russian Federation or the Organization of Petroleum Exporting Countries. Therefore, they offer the United States, China, and the European Union, good perspectives to diversify their energy sources and supplies. ${ }^{6}$

The dispute over the Caspian Sea began with the break-up of the Soviet Union, as it had a clear Caspian frontier with Iran. A series of bilateral agreements between Iran and the Soviet Union defined the Caspian Sea as a

\footnotetext{
$3 \mathrm{http}: / /$ www.spiegel.de/politik/ausland/kaspisches-meer-kompromiss-zwischen-russlandund-iran-mit-stoer-faktor-a-1223130.html 4 https://www.cia.gov/library/publications/the-world-factbook/rankorder/2253rank.html\#aj 5 https://www.eia.gov/beta/international/regions-topics.php?RegionTopicID=CSR 6 Heinrich, A., Pleines, H. (2005), Mixing geopolitics and business:how ruling elites in the Caspian states justify their choice of export pipelines, Journal of Eurasian studies, Volume 6 , issue 2
} 
lake, dividing it equitably between them. ${ }^{7}$ Iran, in discussions with post-Soviet countries, whose coastline is the smallest among Caspian Sea states, has convinced others on either collectively using all of its resources or dividing it into equal five parts. $^{8}$ In 1996 Moscow and Tehran worked together to convince the other states that the Caspian was just a large lake, and all the bordering states needed the consent of the others to extract resources from its bed. ${ }^{9}$ Both states strongly advocated common ownership. ${ }^{10}$

That said, faced with the loss of valuable petroleum resources and its virtual diplomatic monopoly on the territory of the ex-Soviet Union, Russia was compelled to adopt a new strategy of signing bilateral agreements with the newly independent states bordering the Caspian. ${ }^{11}$ Soon Russia, Kazakhstan, and Azerbaijan - effectively split the northern Caspian between each other using median lines. In 1998 Kazakhstan and Russia agreed on the division of the seabed in the Northern Caspian, while the same agreement was signed between Kazakhstan and Azerbaijan in 2001. ${ }^{12}$ Also, the agreement on the delimitation of the seabed between Kazakhstan, Azerbaijan, and Russia was achieved in 2003. Instead of radically defending its argument like Iran, Russia simply signed the bilateral treaties, thus adopting a step-by-step approach while also trying to settle disputes over offshore oilfields. Although these agreements allowed passing some offshore projects such as the Kashagan oil field off Kazakhstan's coast, the disagreement over the sea's legal status has prevented some other projects (e.g.Trans-Caspian Pipeline) from being implemented.

\section{Convention}

The diplomatic negotiations between five states lasted for two decades, comprising 51 working groups, more than a dozen meetings between foreign ministers, and four presidential summits. ${ }^{13}$ The Presidents of the five countries met for the first time in 2002 in Ashgabat, Turkmenistan. The next Caspian summit was held in Tehran (Iran) in 2007, the third one in Baku (Azerbaijan) in 2010, and the fourth summit - in Astrakhan (Russia) in 2014. ${ }^{14}$

7 Zimnitskaya, H., Geldern, J. (2011), Is the Caspian Sea is a sea; and why does it matter, Journal of Eurasian studies, Volume 2, Issue 1

$8 \mathrm{https} / / /$ iranian.com/2018/08/12/iran-russia-caspian-sea-dispute/

9 Mamedov, R. (2001), International Legal status of the Caspian Sea: issues of theory and practice, The Turkish Yearbook, Volume XXXII

10 Zimnitskaya, H., Geldern, J. (2011), Is the Caspian Sea is a sea; and why does it matter, Journal of Eurasian studies, Volume 2, Issue 1

11 idem

12 https://www.pravda.ru/authored/06-12-2017/1358605-kaspiy-0/

13https://www.independent.co.uk/news/world/europe/russia-says-deal-to-settle-status-ofcaspian-sea-reached-a8486311.html

14 https://www.azernews.az/nation/135271.html 
After two decades of diplomatic efforts, the leaders of the five countries signed a convention on the Caspian Sea's legal status on September $12^{\text {th }} 2018$ in the Kazakhstani city of Aktau predicated on "shared usage." 15 The Caspian Sea convention is made of 24 articles $^{16}$ and settles a long dispute over whether to consider it a sea, which would make it accessible by outside countries or to consider it a lake, which would require dividing it equally among its five littoral nations. ${ }^{17}$ The dispute was settled referring to the Caspian as a sea (not a lake) with "a special legal status." The Caspian Sea Convention keeps most of the sea in shared use while dividing up the seabed and underground resources. The littoral states along the bottom of the Caspian Sea can lay underwater cables and pipelines, subject only to the agreement of those countries whose sectors the pipelines or cables will pass through. ${ }^{18}$

However, carving up the seabed resources in the southern part of the Caspian Sea is still the subject of further negotiations as except for Iran the other four countries agree on dividing the sea basin by a line equidistant from the five coastlines. Iran, with the smallest share of the Caspian Sea under the terms of the convention, is considered as a loser in the deal. President Rouhani of Iran, admitting the huge progress and achievement, added that after 20 years of negotiations, only 30 percent of the Caspian Sea issues had been solved and negotiations continue. ${ }^{19}$ According to President Rouhani, in the southern part of the sea, there are still issues between Turkmenistan, Iran, and Azerbaijan. ${ }^{20}$ For instance, the offshore Serdar/Kapaz oil and gas field is still disputed by Azerbaijan and Turkmenistan in the Caspian Sea. Iran and Azerbaijan dispute the ownership of the Araz-Alov-Sharg fields, following a confrontation in $2001 .^{21}$ Although the Sardar-e Jangal field is situated between Azerbaijani and Turkmen territorial waters, Iran has been using its political and military power to explore its oil and gas reserves, which is estimated to contain 10 billion barrels of crude oil.

15 https://www.forbes.com/sites/gauravsharma/2018/08/13/what-does-caspian-seas-newshared-usage-convention-hold-for-oil-and-gas-exploration/\#3f8424bf2043

16 https://www.presstv.com/Detail/2018/08/12/570966/Caspian-legal-status-conventionpresidents-Aktau-Zarif

17 https://astanatimes.com/2018/08/caspian-sea-nations-sign-historic-convention-layingsolid-framework-for-use-of-resource-rich-sea/

18 https://www.strategic-culture.org/news/2018/08/13/caspian-sea-convention-signed-opennew-prospects-for-region.html

19 https://en.mehrnews.com/news/136792/Iran-received-special-privileges-in-Caspian-Sea-

Convention-Pres

20 idem

21 https://oilprice.com/Latest-Energy-News/World-News/The-Political-Consequences-OfIran-And-Azerbaijans-Energy-Agreements.html 


\section{Trans-Caspian Pipeline and Southern Gas Corridor}

Until recent days, the future of the proposed Trans-Caspian Pipeline from Turkmenistan to the European market through Azerbaijan that would bring Turkmen gas to European markets was murky. Russia ${ }^{22}$ and $\operatorname{Iran}^{23}$ both were strongly against the Trans-Caspian pipeline. But now the pipeline project gains a clearer outline as the new agreement states that pipelines only require the approval of the affected states. ${ }^{24}$

Technically, this agreement is a green light for the construction of the Trans-Caspian Gas pipeline from Turkmenistan to Europe through Azerbaijan. The EU looks to Turkmenistan's gas as an alternative to Russia and hopes that it would introduce competition to Russian gas giant Gazprom's monopoly and therefore reduces natural gas prices.

The Trans-Caspian Gas Pipeline is the only feasible way to bring Turkmen gas to European markets as for natural gas, transport by ship requires liquefied natural gas (LNG) terminals, which have very limited capacities in the Caspian region and add considerably to transportation costs. Thus, the only feasible option for the transport of gas across the Caspian Sea, in terms of costs, is a pipeline. However, for both economic and geopolitical reasons, Russia has long rejected the Trans-Caspian Gas pipeline which allows Turkmen Gas to enter to European markets. Turkmenistan owns the 4th largest natural gas reserves in the world behind Russia, Iran, and Qatar. ${ }^{25}$ The Statistical Review of World Energy (2018) indicated that Turkmenistan had 100 million tons of proven oil reserves and $17.5 \mathrm{tcm}$ (trillion cubic meters) of gas. Turkmenistan's emergence as a reliable gas supplier for the EU market would pose a threat to Russian Gazprom's dominant position in Europe. The key market for Russian Gazprom is undoubtedly Europe, which has been its number-one market for 50 years. ${ }^{26}$ In 2016, Gazprom announced that it would strive to maintain at least $30 \%$ share of the EU market in the medium and longrange, and Moscow will likely use every ounce of its political influence to stop the completion of a project that would endanger this stated objective. ${ }^{27}$ According to Petersen and Barysch ${ }^{28}$ Russia's main objective is to prevent Caspian producers from concluding contracts with the Western companies, in particular, Europe, which Russia considers its "captive market." Until now

22 https://www.trend.az/business/economy/2404254.html

23 Sergei Zhil’tsov “Transkaspiiskii proekt,”Nezavisimaia Gazeta, 15 May, 2012

24 https://www.forbes.com/sites/gauravsharma/2018/08/13/what-does-caspian-seas-newshared-usage-convention-hold-for-oil-and-gas-exploration/\#47d933cc2043 25 http://factsanddetails.com/central-asia/Turkmenistan/sub8_7d/entry-4837.html 26 http://www.gazprom.com/press/news/miller-journal/2018/494533/

27 https://globalriskinsights.com/2018/09/despite-caspian-sea-agreement-obstacles-transcaspian-pipeline-remain/

28 Petersen, Barysch, (2011) Russia, China and the Geopolitics of Energy in Central Asia (2011), Center for European Reform 
Kremlins policy was if Central Asian gas is to be exported by a route other than Russia, the gas should go east (i.e., China) than west (Europe), where it would compete against Russian gas in its primary European market. However, in the light of increasing global demand for natural gas led by China, strengthening Western sanctions and desire to improve its leverage over Turkmenistan which increasingly dependent on China as a gas export market ${ }^{29}$, it seems Kremlin has slightly modified its policy towards the construction of the Trans-Caspian Pipeline.

According to Konstantin Simonov, the Director of Russian Fund of Energy Security, the opening of opportunity to build the pipeline from Turkmenistan is a Moscow's signal to European Union to remove all the obstacles along with its project -Nord Stream-2. ${ }^{30}$ The Nord Stream-2 is a pipeline project which adds $3^{\text {rd }}$ and $4^{\text {th }}$ strings to already existing Nord Stream Gas pipeline bringing Russian gas to the European market under the Baltic Sea. The European Commission several times raised concerns about the project creating more legal complications. ${ }^{31}$ The Trump Administration has repeatedly threatened to sanction the project saying it is unacceptable which spread the doubts among the European companies about the future of the project. ${ }^{32}$ As a response to the delay of Nord Stream -2, with an initiative of Russia, a separate protocol was signed on the procedure for assessing the impact of investment projects on the environment by the Caspian states. That protocol enables Russia to delay the construction of the Trans-Caspian pipeline if it goes against its interests. ${ }^{33}$

Another rival of Russia in European markets is Azerbaijan which sits atop 1.3 trillion cubic meters of gas and condensate is also an alternative state to transport for Western energy customers and companies and a key competitor to Russian energy hegemony in the Caucasus. ${ }^{34}$ Currently, Azerbaijan gains its strength not only due to its transit capabilities through projected Trans-Caspian pipeline, but also thanks to the already launched Southern Gas Corridor bringing Azerbaijani gas to Europe. The Southern Gas Corridor which consists of South Caucasus pipeline (SCPx), Trans-Anatolian Pipeline (TANAP) and Trans-Adriatic Pipeline (TAP) makes a $3500 \mathrm{~km}$ journey from the Caspian Sea (the main source is a Shah Deniz Gas field of

29 http://shoebat.org/2018/07/07/ignore-iran-because-the-caspian-sea-shows-that-if-there-isa-threat-it-is-going-to-be-the-war-between-russia-and-turkey/

30 idem

31 https://eadaily.com/en/news/2017/11/08/european-commission-attacks-nord-streams-nobans-but-more-complications 32 https://sputniknews.com/europe/201808191067306171-usa-nord-stream-2-sanctions/ 33 https://www.pravda.ru/world/asia/centralasia/15-08-2018/1391278-caspian-0/\# 34 Russia's Coercive Diplomacy, (2015), Maness, Valeriano 
Azerbaijan) into Europe. ${ }^{35}$ These two gas pipeline projects -TCP and Southern Gas Corridor will turn Azerbaijan into a direct rival of Russia in European markets given the enormous combined reserves of Azerbaijan and Turkmenistan. ${ }^{36}$ To downplay the increasing role of Azerbaijan, its President Ilham Aliyev is expected to offer the transit of part of Russian gas through Southern Gas Corridor to Europe. ${ }^{37}$

Interestingly, Azerbaijani President Ilham Aliyev quickly arranged a visit to Moscow to clarify its ambitions with Kremlin after three weeks of signing the Caspian Sea convention in Kazakhstan. ${ }^{38}$ It is a timely visit as even if Kremlin gave a green light for the Trans-Caspian pipeline, President Putin is still reluctant to see the realization of this project. ${ }^{39}$

\section{Security}

Even if Russia lost its right to veto the construction of pipelines along the bottom of the Caspian Sea, it has gained significant advantages in terms of security issues. Russia and Iran were able to secure a provision in the draft agreement forbidding the presence of armed forces from non-littoral states on the Caspian. The ban of the presence of foreign vessels in the Caspian Sea by five countries was dubbed as "great national security achievement" by President Rouhani of Iran. ${ }^{40}$ The agreement also forbids any of the signatories from letting their territory be used as a base for an attack on another signatory. Interestingly, according to the signed convention, Russia singlehandedly is responsible for the security of the Caspian Sea and Russia's Caspian Flotilla will be guaranteed access to the entire sea. ${ }^{41}$ Although the Caspian region was proclaimed a zone of peace, Russia has kept its fleet in the Caspian Sea until now. Moreover, Russia sent cruise missiles from its warships based in the Caspian at Syrian targets, as Moscow continued intensified bombardments in Middle East Russia deployed its hypersonic aviation-complex Kinzhal to permanent duty throughout the Caspian Sea while Iranian frigate Jamaran together with Russian frigate Tatarstan also patrols it. ${ }^{42}$ Right after signing of Convention, Russia's Defense Minister Sergey Shoigu declared that the main base of the Russian navy in the Caspian

35 https://www.bp.com/en_az/caspian/operationsprojects/Shahdeniz/SouthernCorridor.html

$36 \mathrm{https}: / /$ www.kommersant.ru/doc/3730656

37 idem

38 idem

39 Idem

40 https://en.mehrnews.com/news/136792/Iran-received-special-privileges-in-Caspian-Sea-

Convention-Pres

41 https://www.independent.co.uk/news/world/europe/russia-says-deal-to-settle-status-ofcaspian-sea-reached-a8486311.html

42 https://rueconomics.ru/343395-kazakhstan-podderzhal-plany-rossii-i-irana-po-

kaspiiskomu-moryu 
Sea is going to be transferred from current Astrakhan to Caspian coastal city Kaspiisk. ${ }^{43}$ The underlying reason is to make the Russian navy more mobile and locate it closer to the Caspian Sea. ${ }^{44}$

Stanislav Pritchin, the Head of Central Asia studies of the Russian Academy of Sciences, also states that in terms of security issues, the main winners of Caspian Sea convention are Russia and Iran. ${ }^{45}$ It is well known that Russia's strategic interests in Central Asia are to prevent threats and contain foreign military presence and third-party security alignments. ${ }^{46}$ The clauses of the Caspian Sea convention again demonstrate that security dominates Russian interests in Caspian region. 47 Since Azerbaijan has shown interest in seeing U.S. navy in the region.48 It was Iran's primary concern to contain American presence in the Caspian.

\section{Conclusion}

It is well known that Russia's strategic interests in Central Asia are to prevent threats and contain foreign military presence and third-party security alignments. ${ }^{49}$ The clauses of the Caspian Sea convention again demonstrate that security dominates Russian ${ }^{50}$ and Iranian interests in Caspian region. As a sign of Caspian Sea convention has demonstrated, Russia and Iran were both successful in containing foreign military presence in the Caspian region and demonstrates Russo-Iranian co-operation in the face of U.S. sanctions.

Despite the reluctance of Moscow, Azerbaijan has been able to use its geopolitical and geo-economic position, as well as its energy policy to its advantage. Thanks to the green light to the construction of Trans-Caspian pipeline and currently functioning Southern Gas Corridor, Azerbaijan is continuing keeping distance from the Russian dominance over its energy policy, which has drawn it closer to the American and Western sphere of influence.

Since its independence, Turkmenistan has avoided in participating in Russian-led organizations and regional alliances and has stuck to with its neutrality policy. The absence of President Gurbanguly Berdimuhamedow in a recent summit of Commonwealth of Independent Countries (CIS) presidents

\footnotetext{
43 https://www.kommersant.ru/doc/3667577

44 idem

45 https://ru.sputniknews.kz/columnists/20180810/6775851/kaspijskaya-deklaraciyakazakhstan-azerbaijan.html

46 Idem, pp.90-93

47 Central Asia: Views from Washington, Moscow and Beijing, Rumer, Trenin, and Zhao

48 Akiner, S., Aldis, A. (2004), The Caspian: politics, energy, and security,

RoutledgeCurzon

49 Idem, pp.90-93

50 Central Asia: Views from Washington, Moscow and Beijing, Rumer, Trenin, and Zhao
} 
in Tajikistan is another proof of the policy above. ${ }^{51}$ Given the gas disputes with Russia and Iran in the past, recently China became the only reliable customer of Turkmen gas. Thus, the country has been trying to diversify its export routes to the markets like EU, and Trans-Caspian Gas pipeline is a promising project to realize it.

The settlement of the dispute legalized the division of the Caspian Sea according to the median line which left Kazakhstan with the longest Caspian shore. This allows Kazakhstan to benefit from a stronger framework for the jurisdiction of its giant offshore Kashagan oilfield. Although Kazakh government agreed to provide its Kuryk port in the Caspian Sea to the U.S. logistical supplies for the Afghanistan operations, it is less likely that Kazakhstan will oppose any initiatives in the Caspian region that goes against Russian interests for being the closest allies of Russia. Nonetheless, once the Trans-Caspian Gas pipeline is launched, Kazakhstan might diversify its exports through Azerbaijan to Europe, but still, it will continue using mainly Russian pipelines.

\section{References:}

1. Rumer, Trenin, and Zhao, Central Asia (View from Washington, Moscow, and Beijing,2007

2. Pursiainen, C., Russian foreign policy and IR Theory, Ashgate, 2000

3. Kubicek, P. (2013), Energy and geopolitical competition in the Caspian Basin, Journal of Eurasian Studies

4. Heinrich, Pleines, (2015) Mixing geopolitics and business: How ruling elites in the Caspian states justify their choice of export pipelines, Journal of Eurasian Studies

5. Newnham, R., (2011) Oil, carrots, and sticks; Russia's energy resources as a foreign policy tool, Journal of Eurasian Studies

6. Petersen, Barysch (2011) Russia, China and the Geopolitics of Energy in Central Asia, Center for European Reform CER NOVEMBER

7. Stegen, Kusznir (2015), Outcomes and strategies in the 'New Great Game': China and the Caspian states emerge as winners, Journal of Eurasian Studies

8. The Convention on Caspian legal status Retrieved http://www.kremlin.ru/supplement/5328

9. Kazakhstan Grants U.S. Access to Ports for Afghanistan-bound Goods https://eurasianet.org/s/kazakhstan-grants-us-access-to-ports-forafghan-bound-goods. 